\title{
Towards a new framework for air quality management in Nigeria
}

\author{
A. O. Olowoporoku ${ }^{1}$, J. W. S. Longhurst ${ }^{1}$, J. H. Barnes ${ }^{1}$ \\ \& C. A. Edokpayi ${ }^{2}$ \\ ${ }^{I}$ Air Quality Management Resource Centre, \\ University of the West of England, Bristol, UK \\ ${ }^{2}$ Department of Marine Sciences, Faculty of Science, \\ University of Lagos, Nigeria
}

\begin{abstract}
Since 1988 the Nigerian Government has introduced environmental legislation aimed at reducing the atmospheric impact of various sources of pollution. Emphasis has often been placed on mitigating pollution from the oil and gas industry. However, various studies indicate significant ambient air pollution from other sources due to vehicular traffic growth in urban areas, increased reliance on petrol and diesel fuelled generators for electricity supply in homes and other public facilities, uncontrolled open incineration of waste and major thermal power stations within the city limits. In this paper, we make the case for the establishment of risk-based air quality management approach based on monitoring, modelling and assessment of these other sources. We outline four important elements that should be considered in order to achieve this recommended approach. These elements are conceptualised within the existing institutional, organisational structures and capacity in Nigeria.

Keywords: Nigeria, air quality management, air pollution, air quality standards and objectives, environmental legislation, environmental policy, NESREA, traffic-related emissions.
\end{abstract}

\section{Air pollution as an immediate concern}

Nigeria has a population of 140 million people, a large percentage of which reside in major cities such as Lagos, Kano, Abuja, Port Harcourt and Kaduna (National Bureau of Statistics [1]). Lagos has been identified as one of the fastest 
growing megacities in the world, with the potential of becoming the most populous city in Africa by 2015 (Gandy [2]; Ibem [3]). However, the cost of population growth is not limited to the demand for water, food and energy resources, but also includes the effect of the increased use of such resources on public health and quality of life. Urban population growth implies that the residents of such cities will increase their demand for journeys through vehicular transport means (Chatterton et al. [4]). Traffic-related pollutants, derived from the use of vehicular transport modes such as cars, are associated with effects ranging from poor public health, built and natural environmental degradation and global climate change (Paulley [5]).

Studies have shown that the level of air pollution in Nigeria's major cities is at a level that could lead to respiratory and cardiovascular diseases in vulnerable individuals (Ogunsola et al. [6]; Efe [7]). Without policy and legislative change in air quality management, increasing numbers of Nigerians living and working in its cities and sprawling urban settlements are at risk from poor air quality. Therefore the policy response must include a rigorous, robust and well-informed strategy of reducing the environmental, social and health impacts of air pollution.

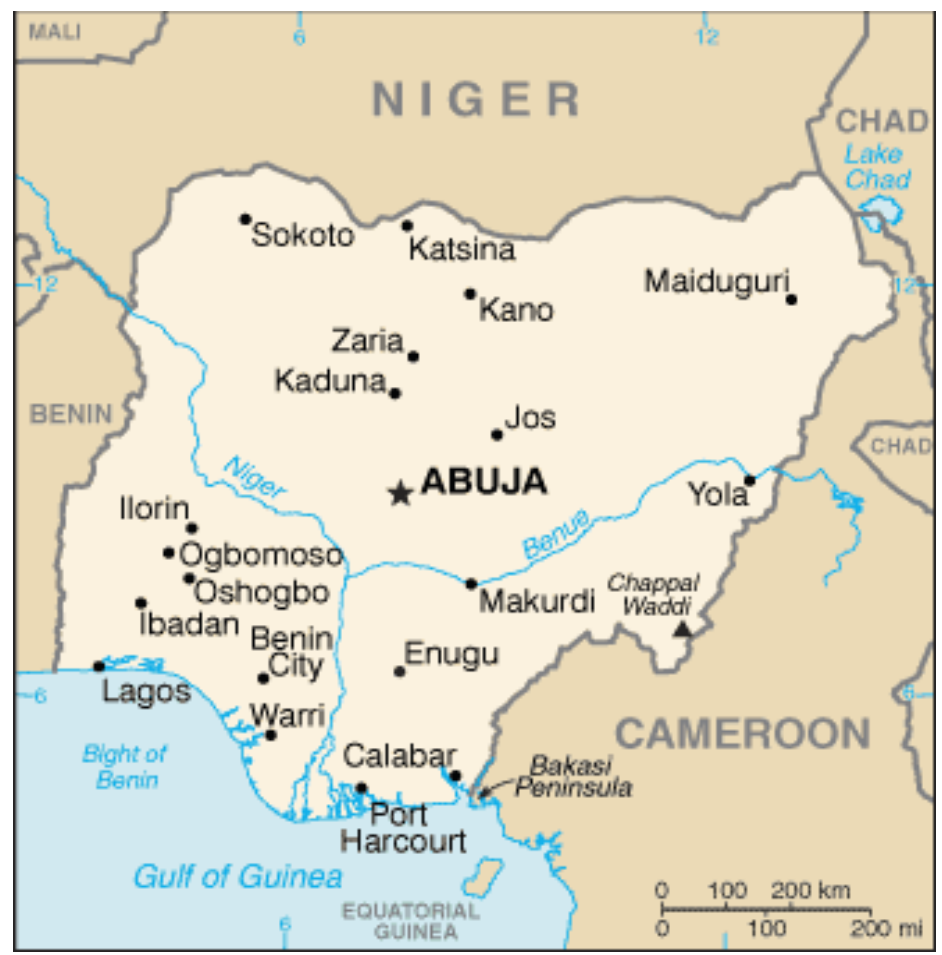

Figure 1: Map of Nigeria showing major cities (US central intelligence agency [8]). 


\section{Institutional and legislative context}

The institutional and legislative frameworks for pollution control in Nigeria have been viewed as inconsistent and too limited to address the scale and nature of urban air pollution (Achi [9]). High population growth, mass migration to unplanned urban developments and under-regulated industrial pollution in large cities present clear and present threats to the environment as well as to the public health of millions (Adegoroye [10]). Legal and regulatory frameworks are weak and in most cases uncertain on the statutory responsibilities and duties of the government with regard to environmental management and protection (Ogunba [11]). The establishment of the Federal Environmental Protection Agency (FEPA) Act in 1988 provided, for the first time, an attempt at coordinating a statutory and institutional response to environmental pollution (Chokor [12]). However, subsequent policies pursued by the government through the Agency were reactive control measures. Most of the policies were directed at regulating pollution from the oil and gas industries without adequate consideration for other sources and their impacts in densely populated areas. (Adegoroye [10]; Ogunba [11]).

The emergence of a new democratic government in 1999 brought, among other things, new hopes for environmental management and protection in Nigeria. The new government created a Federal Ministry of the Environment (FMoE) with a more focused agenda of tackling issues of industrial and urban pollution, marine and coastal resources degradation and the growing threat of desertification. The ministry facilitated major reforms in the environmental legislative and institutional framework. In 2007 the National Assembly repealed the FEPA Act and replaced it with the National Environmental Standards and Regulation Enforcement Agency (NESREA) Act (The Federal Government Printer [13]). The new agency, NESREA, was given the primary responsibility for all environmental laws, guidelines, policies and standards. Part II of the NESREA Act provided statutory enforcement powers and functions of the Agency (The Federal Government Printer [13]). This include responsibilities for "compliance monitoring, the environmental regulations and standards on noise, air, land, seas, oceans and other water bodies other than in the oil and gas sector" (The Federal Government Printer [13]). The corporate strategic plan document published by NESREA identified "improved air quality" as one of the major environmental priorities within its corporate vision (NESREA [14]). In December 2010 the agency undertook a consultation process on various National Environmental Regulations including sections on the Control of Vehicular Emissions from Petrol and Diesel Engines. The establishment of NESREA can thus be seen as a progression from the previous laissez-faire approach to air quality management of previous governments.

\section{Air pollution from traffic-related and domestic sources}

Pollutants from industrial sources, especially from the oil and gas sector in Nigeria have been studied extensively. Sources of emissions include flared gases 
in the Niger Delta, fumes from metal-smelting and cement works, fugitive gases from other chemical and allied industries, and charred particulates and sulphur dioxide emissions from the steel industries (Osuji and Avwiri [15]). These pollutants are not usually confined to the emission point sources. For example, pollutants from flared gases have been observed with concentrations beyond recommended exposure limits in residential communities within $60 \mathrm{~m}$ range of the emission source (Obanijesu et al. [16]). Existing Environmental Impact Assessment (EIA) legislation and other pollution control policies have been disproportionately focussed on regulating the oil and gas industries (Ogunba [11]). Conspicuously ignored were the emerging problems from traffic growth, unplanned urban settlements and dependence on wood and kerosene for domestic energy.

Various studies conducted in Lagos, Abuja, Port Harcourt, Kano, Calabar, and other major cities in Nigeria, attribute significant emissions to transport, domestic and other industrial sources within close proximity of residential areas (Faboye [17]; Iyoha [18]; Magbagbeola [19]; Oluyemi and Asubiojo [20]). A large proportion of the population are increasingly exposed to air pollution due to growth in vehicular transport and consequent congestion in urban areas, increased reliance on petrol and diesel fuelled generators for electricity supply, and uncontrolled open incineration of waste and major thermal power stations within the city limits (Oluyemi and Asubiojo [20]). Pollution from exhaust pipes is often recognisable without measurements, by reduced visibility, adverse smell and eye irritation on most busy roads (Baumbach et al. [21]). In major cities there are high concentrations of $\mathrm{PM}_{10}, \mathrm{NO}_{2}, \mathrm{CO}$ and VOCs with annual mean concentrations many times greater than the WHO or the Nigerian Ministry of Environment acceptable thresholds (Efe [7]; Koku and Osuntogun [22]).

A WHO study in 2007 indicated a growing trend in vehicular-derived air pollution in Lagos due to traffic volume comprising of 2-stroke engines motorcycles (which have higher emissions of particulate matter and un-burnt hydrocarbons than other types of engines) and old imported vehicles (Taiwo [23]). An earlier study also indicated high concentrations of aromatic hydrocarbons, $\mathrm{CO}$ and PM especially in areas within close proximity of bus stops and industries within and around Lagos (Baumbach et al. [21]). The level of CO concentrations in Lagos has been shown to be higher than those found in oil-producing cities in the Niger Delta (Abam and Unachukwa [24]). These findings highlight the significance of other sources, such transport, to air pollution beyond that of oil and gas operations. The UK National Centre for Atmospheric Sciences conducted an aerial emissions estimate studies in Lagos using the Atmospheric Research BAe146 aircraft (Capes et al. [25]). The results showed that emissions are attributed to the evaporation of fuels, mobile combustion and natural gas activities around the city. However, Nigeria is among the few countries with no effective procedures or framework for managing ambient air quality (Koku and Osuntogun [22]). There are no coordinated or continuous assessments to inform an appropriate policy framework to manage the local air pollution that residents of cities such as Lagos routinely experience (Taiwo [23]). 


\section{Pathways to a Nigerian air quality management framework}

While there are various complex political and economic issues that require urgent attention by the Nigerian Government, the need to meet the challenges of urban air pollution is also important. Unlike water, drug or food quality, the impact of urban air pollution is non-discriminatory, and does not recognise the broad social and economic stratum that separate Nigerians. Everyone breathes the same air, including the most vulnerable groups - the children, the elderly and the sick. Managing such a problem requires a cyclic and continuous process. Figure 2 outlines four elements that will be required to initiate and develop a management framework in Nigeria. These elements are conceptualised within the existing institutional, organisational structures and capacity in Nigeria.

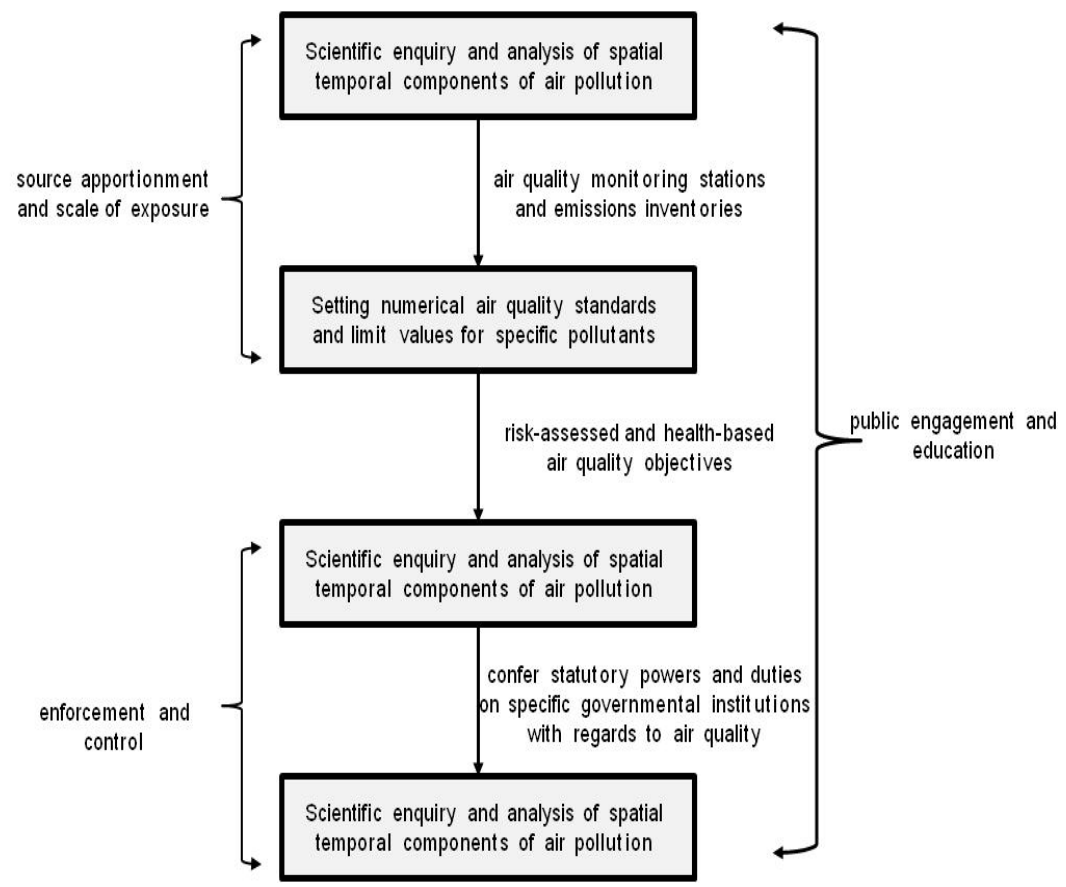

Figure 2: Key elements for developing an air quality management framework in Nigeria.

\subsection{Scientific enquiry and monitoring}

First, there is a need for a government-led scientific inquiry to identify and analyse both the spatial and temporal components of air pollution problems in Nigeria. Such an enquiry will include systematic collation, evaluation and development of an empirical evidence base for ambient air pollution. Deployment of air quality monitoring stations will be necessary across major cities and potential hotspots such as oil and gas production areas. Monitoring air 
quality concentrations across the nation is pivotal to identifying the nature and scale of the air pollution challenge, its sources and impacts. Understanding the science of air pollution provides the ability to assess and mitigate the challenge through robust and evidence-based policies. The body of knowledge on air pollution in Nigeria can be shared and enhanced through research studies and development of professional fora where collaborations and joint-working can be encouraged. An important output of this will be a national emission inventory providing required resources for subsequent air quality assessment, modelling and management options.

\subsection{Standards and objectives}

The scientific recognition of the geography, scale and consequences of the air pollution problem should lead to the determination of relevant standards and objectives against which ambient air quality in Nigeria can be measured. A body similar to the former UK Expert Panel on Air Quality Standards (EPAQS) could be set up and facilitated by NESREA to provide independent advice on concentrations of air pollution at which no or minimal health effects are likely to occur in Nigeria. Although there are still uncertainties with regards to the science of atmospheric pollution, there is sufficient evidence which links poor air quality to a significant public health risk (COMEAP [26]). Based on the best available epidemiological information, the government needs to establish a set of numerical air quality standards and limit values for individual pollutants with the potential to compromise public health. Pollutant concentrations should be riskassessed in relation the costs and benefits of required actions and expressed as air quality objectives setting out the extent to which the government expects the standards to be achieved within a specified timeframe (Longhurst et al. [27]).

\subsection{Legislation and regulation}

Since air quality standards and objectives are designed to protect public health, there is therefore a need for appropriate air pollution regulations to guarantee these standards and objectives. Proposed legislation on air pollution at the National Assembly should include the introduction of regulations, which are shaped by scientific and expert consensus on the definition of the problem. The legislation should introduce a policy framework requiring routine monitoring, assessment and management of ambient air quality to ensure the achievement and maintenance of these standards and objectives. Statutory powers and duties should be conferred on specific governmental institutions such as NESREA or the Federal Ministry of the Environment with regards to air quality. Such powers should include the prohibition and restriction of certain activities or vehicles, the obtaining of information, the levying of fines and penalties, the hearing of appeals and other criteria (HM Government [28]).

\subsection{Management and evaluation}

An important element of the framework is the implementation of legislative requirements to achieve stated air quality objectives. Since the 1980s, the 
Nigerian Government has introduced reactive legislation and developed institutions aimed at reducing the environmental impact of industrial activities (Chokor [12]). Apart from not being robust enough, subsequent policies emanating from such laws were often impaired by limited technical capacity to implement efficient enforcement and compliance regimes (Adegoroye [10]). For example, there is no specific policy framework for managing or mitigating emissions from light-duty and heavy-duty vehicles and trucks, which are thought to be amongst the most significant contributors to air quality in Nigeria (Taiwo [23]).

It is therefore evident that efficient air quality management in Nigeria will rely on suites of proportionate and cost-effective evaluation and management programmes to be undertaken at the local and national level as much as setting standards and regulations. The management framework will need to take account of economic efficiency, practicability, technical feasibility and timescales for achieving legislated air quality objectives. The state government, along with national agencies such as NESREA, will play an important role in setting out and implementing such management procedures. These may include regular reviews and assessments of air quality to identify whether the objectives have been, or will be, achieved at specific geographic locations where public health is, or will be, at risk, by the applicable date. Where applicable, the government should take proactive responsibility for enforcing and implementing appropriate air quality measures that will lead to the achievement of the objectives. This will include source emissions control from both stationary (industries and domestic) and mobile sources (such as transport).

\section{Conclusions}

Establishing an air quality management framework in Nigeria requires the introduction of specific environmental policy reform and legislative changes based on scientific understanding and analysis of the public health risks of air pollution. This paper identifies four important elements that should be considered in order to achieve this. The first element is the development of an empirical evidence base for ambient air pollution through monitoring and analysis of the nature and effect of air pollution problems in Nigeria. The second is the establishment of numerical air quality standards and limit values for individual pollutants with the potential to compromise public health. Third, there is a need for robust legislation and regulations which will guarantee these standards as well as conferring powers and duties on specific governmental institutions such as NESREA and state government agencies with regards to air quality. Last and more importantly, is the introduction of suites of proportionate and cost-effective evaluation and management programmes to be undertaken at the local and national level for achieving the air quality objectives.

Significant gains, in terms of quality of life and public health can be achieved if a Nigerian air quality framework is put in place. There are also economic benefits in developing the capacity of Nigerian environmental professional and academic communities to undertake air quality assessment and modelling 
services. The EIA of development projects such as road schemes, commercial and residential developments, industrial developments, airports and mineral extraction, especially in the oil and gas operations will be enhanced by such skills and expertise leading to better environmental outcomes and improved air quality.

\section{References}

[1] National Bureau of Statistics. Annual Abstracts of Statistics 2009, Federal Republic of Nigeria, 2009. Online http://www.nigerianstat.gov.ng/ [Accessed on 10/06/11]

[2] Gandy M. Planning, anti-planning and the infrastructure crisis facing metropolitan Lagos. Urban Studies. 43 (2), 371-396, 2006

[3] Ibem E.O. Challenges of disaster vulnerability reduction in Lagos Megacity Area, Nigeria. Disaster Prevention and Management 20(1), 27-40, 2011

[4] Chatterton, T., Coulter, A., Musselwhite, C., Lyons, G. and Clegg, S. Understanding how transport choices are affected by environment and health: views expressed in a study on the use of carbon calculators. Public health. 123(1), 45-49, 2009

[5] Paulley, N. Recent studies on key issues in road pricing. Transport Policy. 9(3), 175-177, 2002

[6] Ogunsola, O J., Oluwole, A F., Asubiojo, O I., Durosinmi, M A., Fatusi, A O., and Ruck, W. Environmental impact of vehicular traffic in Nigeria: health aspects. Science of the Total Environment. 146, 111-116, 1994

[7] Efe, S.I. (2008) Spatial distribution of particulate air pollution in Nigerian cities: implications for human health. Journal of Environmental Health Research, 7(2) online. http://www.cieh.org/jehr/jehr3.aspx?id=14688 [Accessed on 10/06/11]

[8] US Central Intelligence Agency. The World Factbook. Online. https://www.cia.gov/library/publications/the-world-factbook/geos/ni.html [Accessed on 10/06/11]

[9] Achi P. B. U., An update on the Nigerian environment. 3rd International Conference on Quality, Reliability, and Maintenance (QRM 2000) Ed. McNulty GJ Oxford Univ England Consortium Int Activ; Inst Mech Engineers. 2000

[10] Adegoroye, A. The challenges of environmental enforcement in Africa: The Nigerian Experience. The Third International Conference on Environmental Enforcement held in Oaxaca, México, April 25-28, 1994

[11] Ogunba, O.A. EIA systems in Nigeria: evolution, current practice and shortcomings. Environmental Impact Assessment Review. 24, 643-660, 2004

[12] Chokor, B. A. Government policy and environmental-protection in the developing world: the example of Nigeria. Environmental Management. 17 (1) $15-30,1993$ 
[13] The Federal Government Printer. National Environmental Standards and Regulations Enforcement Agency (Establishment) Act, 2007. Federal Republic of Nigeria Official Gazette 94(92). 31 July 2007

[14] NESREA. Corporate Strategic Plan 2009-2012: Building Capacity, Enforcing Compliance. A publication of National Environmental Standards and Regulations Enforcement Agency. 2009. Online. http://www.nesrea.org/forms/NESREA\%20CSP.pdf [Accessed on 10/06/11]

[15] Osuji, L.C., and Avwiri G.O. Flared gases and other pollutants associated with air quality in industrial areas of Nigeria: an overview. 2(10), 1277-89, 2005

[16] Obanijesu, E. O., Adebiyi, F. M., Sonibare, J. A., Okelana, O. A. Air-borne SO2 Pollution Monitoring in the Upstream Petroleum Operation Areas of Niger-Delta. Nigeria. Energy Sources Part A-Recovery Utilization and Environmental Effects. 31 (3), 223-231, 2009

[17] Faboye, O.O., Industrial pollution and waste management. Dimensions of Environmental problems in Nigeria, ed. A. Osuntokun, Davidson Press: Ibadan, pp. 26-35, 1997

[18] Iyoha, M.A., The Environmental effects of oil industry activities on the Nigerian Economy: A theoretical Analysis: Paper presented at National Conference on the management of Nigeria's petroleum Resources, Department of Economics, Delta State University Nigeria, 2009

[19] Magbagbeola, N. O., The use of Economic Instruments for Industrial pollution Abatement in Nigeria: Application to the Lagos Lagoon. Selected paper, Annual Conferences of the Nigerian Economic Society PortHarcourt, Nigeria, 2001

[20] Oluyemi E.A. and Asubiojo O.I., Ambient air particulate matter in Lagos, Nigeria: A study using receptor modeling with X-ray fluorescence analysis. Bulletin of the Chemical Society of Ethiopia. 15(2), 97-108, 2001

[21] Baumbach, G., Vogt, U., Hein, K.R.G., Oluwole, A.F., Ogunsola, O.J., Olaniyi, H.B., and. Akeredolu, F.A., Air pollution in a large tropical city with a high traffic density - results of measurements in Lagos, Nigeria. The Science of the Total Environment, 169, 25-31, 1995

[22] Koku, C.A., Osuntogun, B.A., Environmental impacts of road transportation in South-Western States of Nigeria. Journal of Applied Sciences. 7 (16), 2536-2360, 2007

[23] Taiwo, O., Carbon Dioxide emission management in Nigerian megacities: the case of Lagos. Presentation at United Nation Environmental Protection. 2009. Online. http://www.unep.org/urban_environment/PDFs/BAQ09_ olukayode.pdf [Accessed on 10/06/11]

[24] Abam F.I. and Unachukwu, G.O., Vehicular Emissions and Air Quality Standards in Nigeria. European Journal of Scientific Research. 34 (4), 550560,2009 
[25] Capes, G., Murphy, J. G., Reeves, C. E., McQuaid, J. B., Hamilton, J. F., Hopkins, J. R., Crosier, J. Williams, P. I., and Coe, H., Secondary Organic Aerosol from biogenic VOCs over West Africa during AMMA. Atmospheric Chemistry and Physics, 9, 3841-3850, 2009

[26] COMEAP. Long-Term Exposure to Air Pollution: Effect on Mortality. Report produced by the Health Protection Agency for the Committee on the Medical Effects of Air Pollutants. 2009. Online. http://comeap.org.uk /images/stories/Documents/Reports/mortality\%20report\%202009.pdf [Accessed on 10/06/11]

[27] Longhurst, J.W.S., Beattie, C.I., Chatterton, T.J., Hayes, E.T., Leksmono, N.S. \& Woodfield, N.K., Local Air Quality Management as a risk management process: assessing, managing and remediating the risk of exceeding an air quality objective in Great Britain. Environment International 32, 934-947, 2006

[28] HM Government, Environment Act 1995. The Stationary Office: London, 1995 